Pobrane z czasopisma Annales I - Philosophy and Sociology http://philosophia.annales.umcs.pl Data: 26/04/2023 12:16:53

DOI: $10.17951 / \mathrm{i} .2018 .43 .1 .33-53$

A N N A LES

UNIVERSITATIS MARIAE CURIE-SKŁODOWSKA

LUBLIN - POLONIA

VOL. XLIII, 1

SECTIO I

2018

OLHA ROVENCHAK, VIKTORIYA VOLODKO

ORCID ID: https://orcid.org/0000-0003-1301-923X, https://orcid.org/0000-0002-3133-9707

University of Gdańsk

\title{
Comparative Analysis of the Identity and Practices of Post-war Representatives and the Contemporary Wave of Ukrainian Immigrants in the United States
}

Analiza porównawcza tożsamości i praktyk przedstawicieli powojennej oraz współczesnej fali imigrantów ukraińskich w Stanach Zjednoczonych

\section{INTRODUCTION}

Ukrainian migration to the USA has more than a hundred years of history. At the very beginning, it was labour migration of agricultural workers. This migration is known as the "first wave" and took place in the late $19^{\text {th }}$ century. The second (1920-1939) and third (1947-1955) political waves followed the first one. Each of them differed from the others in character and time duration and should be specified within the general flow of Ukrainian migration to the USA. Modern migration (after the 1990s) of Ukrainians to the USA is defined as the "fourth wave". It is characterised by several components, such as labour migration of low-skilled workers, intellectual migration (brain-drain), educational migration and family migration.

The USA has always been on top of the list of states favourable to Ukrainian immigrants ${ }^{1}$. International Organization for Migration (IOM) claims ${ }^{2}$ the number of Ukrainian immigrants in the USA to be about 345,000. At the same time,

1 Migration in Ukraine: A Country Profile, ed. S. Siar, Geneva 2008, p. 22; World Migration: Global Migration Flows, www.iom.int/world-migration [access: 20.12.2017].

2 Ibidem. 
Pobrane z czasopisma Annales I - Philosophy and Sociology http://philosophia.annales.umcs.pl Data: 26/04/2023 12:16:53

according to the latest American census (2014), the number of Ukrainians and people of declared Ukrainian ancestry is 984,000 . It is 20,000 more comparing to $2005^{3}$. Nevertheless, it is difficult to estimate the accurate quantity of Ukrainian immigrants in the USA due to common illegal migration.

Our research is aimed at revealing national, ethnic, cultural and language identities and corresponding practices of the Ukrainians in the USA. We consider researches carried out by M.P. Fedunkiw, S.D. Fink, H. Lemekh, V. Lopukh, B.P. Procko, H. Sarancha, O. Wolowyna as a theoretical background to current study since these scholars discussed some of our subject's aspects in their works. However, they revealed mainly issues of Ukrainian migration in the USA in respect of its structural and cultural characteristics. Thus, identities and practices of Ukrainian immigrants such as Ukrainian national versus Ukrainian ethnic identity, as well as Ukrainian cultural and language identities are still understudied.

Current research is an attempt to analyse sociocultural characteristics, identities and practices of Ukrainian immigrants in the USA and was conducted in 2015 in the form of survey. Forty semi-structured interviews with Ukrainians experiencing living in the USA were collected during the research applying the snowball sampling technique. Also, immigration waves were analysed in terms of their temporal, motivational, duration, quantity and other characteristics. Thus, the discourse analysis and the comparative analysis are the main methodological techniques of this research.

International migration and identity are considered to be the main concepts of the introduced work. Herewith, international migration is seen as a sociocultural process affecting various aspects of immigrants' life, in particular their identity. In its turn, sociocultural identity (identities) influence (influences) practices and behaviour of a person. Since practices are the conventional basis for identity building, the interconnection between an identity and corresponding practices is obvious: identity drives to practices and/or is expressed by them. Such practices can be defined as identification practices ${ }^{4}$.

The historical background of Ukrainian migration to the USA is also an important issue of study regarding building various types of Ukrainian identities.

3 Detailed Languages Spoken at Home and Ability to Speak English for the Population 5 Years and Over: 2009-2013, www.census.gov/data/tables/2013/demo/2009-2013-lang-tables.html [access: 20.12.2017]; People Reporting Ancestry, http:/factfinder.census.gov/faces/tableservices/ jsf/pages/productview.xhtml?pid=ACS_15_1YR_B04006\&prodType=table [access: 20.12.2017].

4 O. Rovenchak, V. Volodko, Miżnarodna migraciia: tieoriia ta praktika, Lviv 2015 (in Ukrainian), chapter 3. 
Pobrane z czasopisma Annales I - Philosophy and Sociology http://philosophia.annales.umcs.pl Data: 26/04/2023 12:16:53

Comparative Analysis of the Identity and Practices of Post-war Representatives... 35

\section{HISTORY}

The first wave of Ukrainian immigrants to the USA is marked by 1877. More than 350,000 people immigrated in the late $19^{\text {th }}$ century to work as strikebreakers in Pennsylvania mines, which were popular immigration destination not only among Ukrainians 5 . Altogether, over 500,000 Ukrainians migrated to the USA between 1870 and $1914^{6} .98 \%$ of Ukrainians were residing in the northeastern states before World War I, 70\% of them - in Pennsylvania'. In the course of time, Ukrainian immigrants traveled from coal mining towns to large cities like Philadelphia or New York in search of factory work. At the same time, the State of New York had also the largest number of Ukrainian agricultural communities in the first decades of the $20^{\text {th }}$ century ${ }^{8}$. Up till 1899 , a record of immigrants' country of origin rather than their nationality or ethnicity was kept by the United States immigration authorities. Most of the early groups of Ukrainians came from the areas of Carpathian Ukraine and Galicia, then a part of the Austro-Hungarian Empire and some of them came from Central Ukrainian areas, then a part of Russia. It was the time when Ukraine didn't legally exist as a political entity, and most of these immigrants were called Carpathian Russians, Rusyns, Russians, Ruthenians, Poles, Austrians but not Ukrainians. Besides, Americans were generally unaware of Ukraine as an independent state. That means that next generations and next waves of immigrants were forced to explain political reality of their homeland, thus reinforcing their ethnic identity9.

As opposed to the first, economically (labour) labelled immigration wave, the second wave of Ukrainian immigration to the USA was mostly political. This wave, covering the period between 1920 and 1939, was considerably shorter in time than the previous one, numbering from 15,000 to 20,000 immigrants according to different estimations. The reason for emigration for the majority of this wave was the failed 1917-1920 endeavour to re-establish Ukraine as an independent state ${ }^{10}$. Due to the second wave, Ukrainian communities in the USA got extended by the

5 D. Morris, 'Gone to work to America': Irish step-migration through south Wales in the 1860s and 1870s, "Immigrants \& Minorities" 2016, Vol. 34(3), pp. 297-313.

6 Ukrainian Immigrant Dwellings and Churches in North Dakota from Early Settlement until the Present, National Register of Historic Places, The State of North Dakota, 1987.

7 M.P. Fedunkiw, Ukrainian Americans, www.everyculture.com/multi/Sr-Z/Ukrainian-Americans.html [access: 20.12.2017].

8 W. Halich, Ukrainian farmers in the United States, "Agricultural History" 1936, Vol. 10(1), pp. 25-39.

9 Ibidem; S.D. Fink, From 'Chicken Kiev' to Ukrainian recognition: Domestic politics in U.S. foreign policy toward Ukraine, "Harvard Ukrainian Studies" 1997, Vol. 21(1/2), pp. 11-61.

10 M.P. Fedunkiw, op. cit.; S.D. Fink, op. cit. 
Pobrane z czasopisma Annales I - Philosophy and Sociology http://philosophia.annales.umcs.pl Data: 26/04/2023 12:16:53

influx of anti-communist-minded Ukrainians with explicit sense of their national belonging and ethnocultural identity.

The third wave brought up to 85,000 Ukrainians to the USA between 1947 and 1955. Most of these immigrants were former prisoners of the postwar refugee camps in Austria and Germany. This wave is characterised by emigrants from the western region of Ukraine, Galicia. It should be mentioned that Galicia had been annexed by the USSR in the result of World War II. Third-wave comers, these Ukrainians were nationally conscious (aware of their Ukrainian identity) and were fleeing from political persecutions, seeing the USA as a temporary home. They had little or no intention to return Soviet Ukraine. However, most of them would have never returned to their motherland and settled down in America. Many of these Ukrainian immigrants were well-educated doctors, lawyers, engineers, etc., but at first times had to take any jobs, often low-paid, to maintain their families. Some of them had never returned to their professions, and some took charge of administering Ukrainian organisations. Unlike the first-wave immigrants who generally settled in coal regions of rural Pennsylvania, the second and third waves brought Ukrainians to large cities like New York, Philadelphia, Pittsburg, Cleveland, Detroit, Chicago. What is more, the newcomers tried not to lose touch with their ethnic fellows and tended to settle down in the areas with dense population of American Ukrainians, with well-developed community facilities like churches, clubs, etc., where they felt themselves at home and could enjoy maintaining their national identity ${ }^{11}$. This was also the last wave of Ukrainian migration to the USA whose partakers appreciated the benefits of living in Ukrainian diaspora areas. At the beginning of the $21^{\text {st }}$ century, the survivors of these post-World War II (further abbreviated as post-WWII) wave immigrants represent only $10 \%$ of all the Ukrainians in the USA ${ }^{12}$.

Ukrainian immigrants of the fourth wave started their trip to the USA in 1989, after a three-decade break. Statistics counts about 200,000 of these immigrants ${ }^{13}$. It resembles the first wave in nature since it is self-motivated, mostly voluntary economic migration unlike the migrations of the two in-between waves. The conceptual incongruences between the third and fourth waves have brought forth the subject of current research. Since it is impossible to explore by live questioning the peculiarities of the first and second waves as they took place in far-away times, we have nevertheless managed to engage the third wave's representatives who are already in their late seventies and older, and of course the fourth wave immigrants.

11 M.P. Fedunkiw, op. cit.; S.D. Fink, op. cit.

12 O. Wolowyna, Recent migration from Ukraine to the United States: Demographic and socio-economic characteristics, "The Ukrainian Quarterly" 2005, Vol. 61(3), pp. 253-269.

13 V. Lopukh, The effects of the 'Fourth Wave' of immigrants from Ukraine on the Ukrainian diaspora in the United States, "Demography and Social Economy" 2014, Vol. 1(21), pp. 192-202. 
Pobrane z czasopisma Annales I - Philosophy and Sociology http://philosophia.annales.umcs.pl Data: 26/04/2023 12:16:53

Comparative Analysis of the Identity and Practices of Post-war Representatives... 37

\section{RESEARCH RESULTS}

\section{Nationality}

When asked about national identity, respondents usually appeal both to Ukraine and the USA in the sense of belonging. Ukraine is considered as a state of lifetime belonging while the US is viewed as a state of present, or temporary belonging. They appreciate the chance of living in the USA and having better conditions here than in Ukraine. The main difference between the two countries, as marked by majority of the respondents, is the rule of law and order in the USA and its abuse in Ukraine:

$[\ldots]$ this is the country where the laws are obeyed, this is the country where the rules are followed. If one follows and imitate them, one can make a successful career and consequently enjoy his own life with the feeling of being respected and appreciated. The feeling I had never had in Ukraine - I had no feeling that I was appreciated or valued by the state (Olya, 45 y.o.).

[...] my rights here, however vulnerable as a migrant's rights, are anyway better protected than my civil rights as a legal citizen in Ukraine had been (Lyudmyla, 45 y.o.).

The respondents also express their dissatisfaction concerning corruption in Ukraine, which is widely spread on every level of state governance.

The survey reveals that Ukrainians do not support any of Ukrainian state authorities (the president, government) that had ever been in power. Nevertheless, the respondents regard themselves as Ukrainian patriots, detaching authorities from the state. The surveyed American Ukrainians maintain their connection with the homeland exercising certain practices which add to the sense of belonging to Ukraine. Such practices are as follows:

- participation in demonstrations in support of independence of Ukraine (from the 1950s till 1991): "There were thousands and thousands of people. I was a little girl, 8-9-10 years old, my sister was a little bit elder. Our parents took us to New York and we marched there. We were in Ukrainian traditional dresses; there also were other nations there in their own traditional dresses. Thousands of us marched to show our posters with... 'Ukraine' [...]" (Lyuba, 73 y.o.),

- support of democratic "revolutions" in Ukraine (the Orange Revolution in 2004, the Maidan in 2013-2014),

- support of Ukraine in war against Russian military invasion (started in 2014 in Donbas region): "There is an organisation in New York [...] we analyse articles released in the information space. That is, we examine, what kind of information about Ukraine has been published. I read as many of these articles a day as I can 
and then conclude whether the information is positive or negative. The point is, we have to know the sources of the information" (Halya, 36 y.o.),

- explanation the existence of Ukraine as an independent state is a rather specific kind of national practices associated with national identity. The respondents usually have to explain to Americans that Ukraine is an independent state, not a part of Russia as it is generally assumed by mass: "[...] until the recent events in Ukraine, Ukraine had been perceived as a part of Russia and we had to tell them, explain that Ukraine is an independent state and we have different languages, different cultures" (Olya, 45 y.o.); "[...] so, I had to teach him [my husband] more so that he could understand that Ukraine is not Russia, neither it is a piece of Russia, that Ukraine indeed is a state of its own, with its own history, language and so on" (Lyuba, 73 y.o.),

- engagement in pro-Ukrainian charity. They provide financial support to the Ukrainian army, orphanages, a medical and educational institution in Ukraine.

It is our personal view, based on some observations, but there is a high probability that there are a lot of former Ukrainian residents in the USA who did not support the Maidan ${ }^{14}$ and now support Russia in Ukrainian-Russian conflict, but we did not happen to have them as our interviewees. The matter is, many of these immigrants identify themselves not as Ukrainians (nationally, ethnically, culturally, by language), but rather as Russians, Russian-speaking, (post-)USSR-residents, and they failed to get enrolled in the interview since nationalities other than Ukrainian were out of the scope of this study.

It is widely admitted that citizenship is a marker of national belonging and usually influences national identities and practices. All the respondents of the current survey, representing the third migration wave, are US citizens, and majority of the fourth wave migrants either have already become US citizen or are on the way to it. Strange as it might sound, they consider American passport as a means to facilitate foreign travels but in no case the reason to reject Ukrainian ethnical belonging.

Having conducted the comparative analysis between the results of current research and such on Ukrainian migration to Poland (2008-2010), Greece (20082010), Germany (2014) $)^{15}$, we have to admit that Ukrainians in the USA do not con-

14 Protesting actions in Ukraine (November 2013 - February 2014) against the regime of the former president Yanukovych, against corruption and for the European vector of Ukrainian political development distinguished by rude attempts of the police forces to disperse the rebellion. The Maidan is also known as the Euromaidan.

15 For details, see O. Rovenchak, V. Volodko, op. cit.; O. Rovenchak, Sociokulturni osobliwosti suczasnoï ukraïns'koï jemigracï do Nimieczczini, “Odesa National University Herald. Sociology and Politics" 2016, Vol. 21(1) (in Ukrainian), pp. 71-90; V. Volodko, Jemigraciia z Ukraïni ta 
Pobrane z czasopisma Annales I - Philosophy and Sociology http://philosophia.annales.umcs.pl Data: 26/04/2023 12:16:53

Comparative Analysis of the Identity and Practices of Post-war Representatives...

sider US citizenship as a means of successful integration into the receiving society, but rather as an instrument favouring to simplify their lives, especially when it comes to trips abroad, as opposed to the concept of citizenship circulating among Ukrainian immigrants in European countries. Most probably, the reason is in the fact that the USA is traditionally a state of and for immigrants, and the concept of "immigrant" is not perceived there as "poorly adapted". Migration process is rather the norm than an exception to the country's life. One more reason to take US citizenship is respondents' intention not to leave the USA for another country, or to return to Ukraine either for temporal or permanent residence, unlike the situation with Ukrainian immigrants in European countries, where spatial mobility is well-developed on the inter-state level.

Prevailing majority of the respondents expressed negative attitude to the former state of the Soviet Union. It should be pointed out that both the third and fourth wave immigrants are unanimous in their negative opinion about the USSR. They regard migration to the USA as an escape from the Soviets and Soviet heritage in Ukraine. It is not strange, though, that newcomers often call immigrants from former Soviet republics "our" or "more our" than others.

It is worth mentioning that the third and fourth migration waves are very similar in terms of their character and manifestation of national identity, as it can be judged from the interviews. In particular, representatives of both waves are engaged in charity and/or demonstrations in support of Ukraine's independence from Russia, explanation of Ukrainian history (they had always been doing it, yet prior to Ukraine's independence in 1991); moreover, post-WWII immigrants have the same attitude towards modern Ukrainian authorities (governments and presidents) as "newcomers".

Quite an unexpected discovery to us was the fact that respondents representing post-WWII immigration wave who came to the USA as children or teenagers, got American citizenship and have been living in the USA for 60-70 years, still have no strong American national identity. They claim their respect to the USA as a state, they like to live here and are grateful for the chance of having a decent life as opposed to the alternative to get deported to Siberia ${ }^{16}$ in case they had stayed at home. Nevertheless, the respondents of this group still refer themselves to Ukraine as a state which they were forced to leave with no chance of legal belonging, unlike the fourth wave migrants who were free in their choice:

Polszczi. Pierietworiennia migracijnich rieżymiwk, [in:] Social science: Past, Present and Future. Collection of Papers of International Conference (Kyiv, September, 5-6, 2014), Kyiv 2014 (in Ukrainian), pp. 36-39.

16 The reasons for emigration usually were parents' relation to Ukrainian bourgeoisie, intelligentsia, or Ukrainian national liberation movement. 
I did not want to go to America from Germany... We were political emigration because we did not want to live under the communist regime, and we could not come back home, since many of those who had returned just disappeared, or were deported to Siberia and we knew that... I must be loyal to the state that gave me asylum, gave me a chance to get some education and live in a state with freedom of speech, freedom of religion, freedom of nationality, national belonging, and prevented me from returning to the place where I was nothing but to die, or with a bit luckier alternative, to be deported to Siberia (Andriy, 84 y.o.).

In our opinion, this is exactly the reason why these post-WWII wave immigrants strive to save all and everything Ukrainian that could be saved and preserved in emigration. This also might be the reason for establishing and functioning such a great number of Ukrainian communities and organisations in different cities of the USA ${ }^{17}$.

Concerning Ukrainian political issues, the third wave respondents are often better aware of political situation in Ukraine in 1940-1950s than of the present times: "I am not a member of any party, I support Ukrainian community. But they are always struggling there in politics. Some of them are banderivci and the others are melnykivci" (Vira, 76 y.o.) ${ }^{18}$. This could be explained by the respondents' feeling of 1940s Ukraine and not of contemporary stage of Ukrainian political development. The difference between the Ukraine they remember, they have been dreaming about for decades and modern Ukraine could be one more explanation of the disappointment circulating among this immigration group about modern processes of Ukrainian state building.

The survey has also revealed discordance in the attitude of representatives of the two waves towards immigrants from former Soviet republics. Respondents of the third wave do not associate themselves with this group of immigrants and never call them "our". This is obviously because they never lived (or lived for a very short time) in the same state (USSR) with these nations. The interviewed Ukrainian immigrants of this group in no way refer themselves to Russian-speaking communities and/or Russian speakers. These respondents express their incomprehension of Russian-speaking newcomers from Ukraine calling themselves Ukrainians. The misconception occurred, in particular, when the third wave immigrants met Russian-speaking Ukrainians of the fourth wave supporting the Maidan, Ukraine and Ukrainian army in its armed conflict against Russian troops in Donbas:

[...] they take part in protests, some demonstrations which, by the way, our wave also joins, but they organise this... In the beginning, she [a member of the Ukrainian community, a newcomer]

17 Their list is available in Migration in Ukraine..., pp. 54-59.

18 The supporters or S. Bandera and A. Melnyk, the leaders of different wings of Ukrainian national liberation movement of 1940-1950s. 
Pobrane z czasopisma Annales I - Philosophy and Sociology http://philosophia.annales.umcs.pl Data: 26/04/2023 12:16:53

Comparative Analysis of the Identity and Practices of Post-war Representatives...

had also spoken Ukrainian but then turned to Russian. This is strange to us. Do you know why? People do know how much language, the mother tongue, is important to the state, [...] and why do they? - Because it is profitably more convenient. It irritates us, but we try to understand, because either this Ukrainian youth or their parents, many of them, were afraid to speak Ukrainian because they could have been accused of nationalism, chauvinism. But we need some time to accept this (Andriy, 84 y.o.).

Hence, national identity of Ukrainians in the USA is not homogeneous and is rather complicated in nature. Immigrants, as a rule, get assimilated with locals, undertaking thus American cultural component, at the same time preserving, cherishing and facilitating their national Ukrainian identity. H. Lemekh ${ }^{19}$ comes to similar conclusion talking about fluent articulation of Ukrainian constituent component of immigrants' national identity. The degree of emphasis on the national identity depends on the duration of living in the USA, on the respondent's personal life circumstances, on the citizenship and degree of integration into American society. One more factor, from our point of view, is the Soviet constituent element of national identity, characteristic of the "new" wave Ukrainian immigrants in the USA.

\section{Ethnicity}

Ethnic identity is a sense of belonging to definite ethnic community. It includes ethnicity - rather emotional, than actual belonging to ethnical community, and actual belonging that undertakes some common activity ${ }^{20}$. H. J. Gans also considers two forms of ethnic identity, surface and deep. Surface form includes self-naming and self-identification. Deep form implies reinforced ethnicity and related common activity ${ }^{21}$. B. Azhnyuk exemplifies Ukrainian immigrants to emphasise the difference between national and ethnic identities. Their first generation called themselves Ukrainians, meaning their belonging to Ukraine and Ukrainian ethnos, but their second generation called themselves Ukrainians meaning just belonging to Ukrainian ethnos ${ }^{22}$.

Respondents in our survey express their sense of belonging to Ukrainian ethnos either just stating: "I am a Ukrainian" or sometimes introducing definite

19 H. Lemekh, Ukrainian Immigrants in New York: Collision of Two Worlds, El Paso 2010, pp. 61-83.

20 A. Kofler, Migration, Emotions, Identities. The Subjective Meaning of Difference, Wien 2002, pp. 12-13.

${ }_{21}$ H.J. Gans, Toward a reconciliation of 'assimilation' and 'pluralism': The interplay of acculturation and ethnic relation, "International Migration Review" 1997, Vol. 31(4), p. 882.

22 B. Azhnyuk, Natsional'na identychnist' i mova v ukrayins'kiy diaspori, "Suchasnist" 1999, Vol. 3 (in Ukrainian), p. 137. 
ethnic activity like: "I am a Ukrainian since I practice lots of Ukrainian tradition, namely [...]". However, many respondents' ethnic identity is not isolated from national one, especially those of the post-WWII wave.

Besides the sense of belonging to Ukrainian ethnos, Ukrainian ethnic identity includes practices demonstrating this identity. This sort of practices is represented by the following Ukrainian ethnic traditions, customs, rituals:

- national cuisine (the food immigrants cook and eat),

- traditional holidays, especially Christmas and Easter,

- ethnic embroidery (vyshyvanka),

- folk music, songs, dances.

I wear vyshyvankas, we celebrate Easter according to Ukrainian traditions and we celebrate Christmas as it is celebrated in Ukraine: we gather on Christmas Eve at my sister's place and eat Ukrainian dishes there, the ones we ate in Ukraine: kutya ${ }^{23}$, and others, dumplings, borsch ${ }^{24}$. I listen to Ukrainian music. [...] Ukrainians can be here and there, we maintain Ukrainian traditions and culture both here and there because we want Ukrainians to speak Ukrainian here, for them to come here and speak Ukrainian [...] (Viktoriya, 34 y.o.).

All the dishes I cook are Ukrainian. When holidays come we celebrate Christmas, all the family living here come together, with children, actually, they are not children anymore. This is our old tradition and we follow it, and our children are brought up to it (Sonya, 91 y.o.).

Development of ethnic infrastructure relates to the ethnic traditions described beneath. Under the term "ethnic infrastructure" we mean specialised shops selling goods from Ukraine (mainly food). We must admit that this element of infrastructure is important first of all for the newcomers because these shops provide them with the goods they had got used to in Ukraine. We also consider Ukrainian churches, which facilitate ethnic practices, as an essential element of ethnic infrastructure.

Ukrainian churches and schools were actually main pro-Ukrainian infrastructure objects. They have always been interconnected. Until the middle of the $20^{\text {th }}$ century, Ukrainian communities preferred to send their children to Ukrainian schools instead of public grammar schools with auxiliary provision of Ukrainian ${ }^{25}$. This fact testifies self-segregation processes within first two waves of immigrants. The situation changed only with the third immigration wave. Nowadays, Ukrainian schooling in the USA exists mainly in form of

23 Ukrainian traditional Christmas dish.

24 Ukrainian national dish served as the first course.

25 M.J. Nagurney, The teaching of Ukrainian in the United States, "American Slavic and East European Review” 1945, Vol. 4(3/4), pp. 186-194. 
Pobrane z czasopisma Annales I - Philosophy and Sociology http://philosophia.annales.umcs.pl Data: 26/04/2023 12:16:53

Comparative Analysis of the Identity and Practices of Post-war Representatives...

extracurricular education at Saturday/Sunday schools, and counts about 40 of such schools with 2,500 pupils $^{26}$.

Ukrainian churches have been the main institutions of Ukrainian diaspora since its earliest days. The first Ukrainian church was established in 1886 in Pennsylvania. During the whole history of Ukrainians in the USA, one of the most obvious functions of church was ministering spiritual life, but of course its range of influence is quite universal since church has also been providing parish's educational needs, arranging numerous cultural events and holiday-feast day celebrations. Ethnic identity has also been promoted by traditional arts: dancing, choral singing, theatres. Crafts such as making traditional holiday clothes (vyshyvanka) and painting Easter eggs (pysanka) have been preserved until present ${ }^{27}$. The most popular Ukrainian church in the USA is the Ukrainian Catholic Church. This institution was persecuted and abolished in the USSR after World War II due to specific political situation. The reason was not religious aspects of church's activities but rather its national character. However, it has been successfully functioning in the diaspora. In this sense, Ukrainian American Church is called one of the leading symbols and vehicles of Ukrainian nationalism in the Soviet period of Ukrainian history and Ukrainian Catholicism got the definition of "ethnoreligion" (religion of this ethnic group $)^{28}$.

Therefore, Ukrainian churches can also be considered as specific local organisations performing both religious and social functions. Functioning of these churches has ensured reproduction of ethnic practices for several waves of Ukrainian immigrants in the USA for many decades:

[...] we do our best to cultivate that the church and community are a kind of centre of Ukrainian life. Not just spiritual, but also social life, cultural life, traditional Ukrainian life. You know, wherever Ukrainians had come, the first thing they did was building a church. Having a church means having a community, having a centre uniting all the emigrated Ukrainians [...] it is the place which joins people of the same language and culture (Volodymyr, 38 y.o.).

And this all is the history of Ukrainians. Everywhere our generation had come. I mean [19]48, $50,51,52$ years. The main task was to build a church in order to preserve the Ukrainian language, to save history, for children not to forget about Ukraine [...]. It means language, culture, music, all these things were the most important to our parents who had come with kids (Lyuba, 73 y.o.).

26 Ch. Vasylkiv, Ukraïns'ka szkoła w SSZA: istoriia, problemi, pierspiektiwi ta rozwitok, "Theory and Practice of Teaching Ukrainian as a Foreign Language" 2014, No. 9 (in Ukrainian), pp. 279-290.

27 Ukrainian Immigrant Dwellings and Churches...

28 B.P. Procko, The Ukrainian Catholic Church, 1945-1975, [in:] A Symposium Held at La Salle College in Philadelphia, Pennsylvania, April 19, 1975, eds. M. Labunka, L. Rudnytzky, Philadelphia 1976; idem, Ukrainian Catholics in America: A History, Washington 1982; idem, Ukrainians in Pennsylvania: A Contribution to the Growth of the Common Wealth, Philadelphia 1976. 
Pobrane z czasopisma Annales I - Philosophy and Sociology http://philosophia.annales.umcs.pl Data: 26/04/2023 12:16:53

Besides local church organisations, there are many other official organisations of Ukrainian diaspora in the USA, and herewith interviewed Ukrainian immigrants participate (participated) in these organisations. These are, for example, the "House of Ukraine" (San Diego), the "Ukrainization" cultural centre, Shevchenko Scientific Society, UCC (Ukrainian Culture Center), UCCA (Ukrainian Congress Committee of America), CCAU (Coordinating Committee to Aid Ukraine), UNWLA (Ukrainian National Women's League of America), UUARC (United Ukrainian American Relief Committee), UDYA (Ukrainian Democratic Youth Association), CYM (Ukrainian-American Youth Association), PLAST (Ukrainian Scouting Organization in the USA), CAAU (California Association to Aid Ukraine).

It should be noted that participation in official Ukrainian organisations is typical for the third wave immigrants and all the respondents of our survey of this group were or still are the members of such organisations. However, ethnic practices of the post-WWII immigrants are more institutionalised as compared to ethnic practices of the newcomers. Although some newcomers participate in Ukrainian organisations established by the "old" wave (waves), the "new" wave immigrants" organisations are usually non-formal, not officially registered, and have no governing body. To these belong non-formal communities, online communities, groups in social networks, in particular the ones established in connection with supporting the Maidan and Ukraine in conflict against Russia: "There is, for example, an online organisation 'Maidan San Diego', counting about 200 persons" (Oleh, 57 y.o.); "[...] I am coming here to Ukrainian culture centre, but I do not consider it as an organisation" (Ihor, 56 y.o.).

Contemporary immigration wave to the USA has encountered the organised life of Ukrainian diaspora here. Numerous Ukrainian organisations (cultural, social and political) served as diplomatic missions representing Ukraine. The role of Ukrainian diaspora in disclosing Russian invasion into Ukraine to the world community cannot be overestimated ${ }^{29}$. Representatives of Ukrainian diaspora rested their hopes on newcomers to stiffen Ukrainian organisations in the USA. To their disappointment, younger generation failed in it. The fourth wave immigrants' participation in such organisations is rather an exception than a rule. This can be explained through miscomprehension of political views and language issues.

The point is that the third wave is considered as forced migration caused by political motives, and the immigrants were patriots and strong supporters of the independence of Ukraine in their majority. They treated the "newcomers" (i.e., the fourth-wave immigrants) with caution since the latter were driven by economic

29 H. Sarancha, Suczasna jemigraciia w SSZA: problemi adaptaciï ta zbierieżennia widnosin z Ukrä̈noju, „Naukovi zapysky Ternopil'skoho nacional'noho pedahohichnoho universytetu im. Volodymyra Hnatjuka. Serija Istorija” 2010, No. 2 (in Ukrainian), pp. 248-253. 
Pobrane z czasopisma Annales I - Philosophy and Sociology http://philosophia.annales.umcs.pl Data: 26/04/2023 12:16:53

Comparative Analysis of the Identity and Practices of Post-war Representatives...

motives and were free in their choice. These people were seeking a better life, not safety or asylum. One more disparity is caused by the principle the fourth-wave immigrants have been choosing their place of residence. It is completely different from the post-WWII immigrants' one. The newcomers prefer to settle not in the regions of traditional Ukrainian diaspora settlement, but in the regions, where they expect the best work opportunities ${ }^{30}$. For instance, Philadelphia, New York, Chicago are popular with both migration waves. But Oregon, Washington, Sacramento are new trends in Ukrainian immigration settlement while Pennsylvania and Omaha are losing the percentage of Ukrainian population in their infrastructure $^{31}$. Another reason for misunderstanding is language issue. On the one hand, the problem is in Russian-speaking newcomers, on the other hand - in speaking "archaic" Ukrainian (using Ukrainian archaisms, Polish words, English-structured phrases and sentences) by the diaspora ${ }^{32}$. These issues will be discussed in more detail further in the current paper.

One more contradiction between the last two waves of Ukrainian immigration which should not be omitted is the substitution of ethnic identity and practices for cultural ones by newcomers. Further on, we will talk about this practice.

As can be considered from the questioning experiment, many of the above-discussed practices correspond with both national and ethnic identities simultaneously. Cultural identity is also associated with these identities.

\section{Culture}

Cultural identity (in its narrow meaning) is the result of identification with definite local or global sociocultural community following certain values, norms, practices, morals, rituals, ways of living. In our case, we consider the superculture of the society of emigration (Ukraine) and immigration (USA) including ethnic culture as well as the elements of these societies' subcultures and of world (global) culture as its integral element. Such cultural identity is not to be equal with ethnic, national, or other identities ${ }^{33}$.

The notion of transference between ethnic and cultural identity has appeared in classification of non-ethnic cultural practices widely spread in modern Ukraine as "Ukrainian". It concerns, for example, dishes, books, films. At the same time,

30 O. Wolowyna, op. cit.

31 V. Lopukh, op. cit.

32 H. Sarancha, op. cit.

33 This research is not aimed to study American constituent element of cultural identity of Ukrainians in the USA and its correlation with Ukrainian and other ethnic ones. We are concentrate on Ukrainian constituent element. 
with the respondents - representatives of the post-WWII wave, clear distinction of ethnic Ukrainian and American practices as well as practices of the ethnos/state of the spouse's origin is observed.

The matter is that post-WWII immigrants emigrated from Ukraine in 19401950s and had no chance to experience cultural practices related to Ukraine as a part of the USSR as well as Ukrainian cultural practices affected by globalisation processes. The fact that the respondents and their parents, living in a new place for decades and consciously doing their best to exercise particular ethnic practices, did add much to Ukrainian identity among the diaspora in America. Their reason was to preserve pure Ukrainian culture in the USA for next generations living in independent Ukraine to exercise them in the future:

The most important for our parents was to preserve the knowledge about Ukraine, Ukrainian language, Ukrainian history, Ukrainian music... It was the most important for them to preserve all this here in the free world. Because they hoped, I think. Yes, they hoped that one day Ukraine would be free (Lyuba, 73 y.o.).

Actually, I [the newcomer] learned to paint pysankas here, in America. A woman who was born here and represents the third generation of Ukrainians, and she taught me to paint pysankas (Olya, 45 y.o.).

In general, cultural identities and corresponding practices have different values for Ukrainians of the two waves. The core element of Ukrainian cultural identity of the post-WWII immigrants is their belonging to Ukrainian state and Ukrainian ethnic culture. Ukrainian immigrants of the fourth wave, however, have obviously suffered from the Soviet influences Ukrainian and got affected by modern globalisation processes.

\section{Language}

Language identity is one more important component of ethnic and cultural identification. Till a person identifies himself/herself with the language of his/her ethnos, language identity could be the basis for ethnic identity. These identities still should not be viewed as congruous. We have to differentiate between them, for example, with Russian-speaking Ukrainians, and in other similar cases. Language identity is determined by a set of factors (mother tongue, language of everyday use, language of one of the parents, language of a spouse, official state language, language of education/business, etc. ${ }^{34}$. Each case forms an individual hierarchy of recounted factors determining language identity of a person. 
Pobrane z czasopisma Annales I - Philosophy and Sociology http://philosophia.annales.umcs.pl Data: 26/04/2023 12:16:53

Comparative Analysis of the Identity and Practices of Post-war Representatives...

Learning the official language of the receiving state is one of the most important motivational forces of immigrants' adaptation. Most of the respondents in our research had been learning English before they came to the USA; nevertheless, they usually did not speak it well due to shortcomings of education system in Ukraine, the lack of language practice and learning British English. A few of the respondents did not speak English at all and had to learn it from scratch in the USA. Some of the respondents spoke English badly and therefore had to use translators. However, a couple of respondents spoke English very well yet before coming to the USA. They are graduates of foreign languages faculties and some of them even teach English in the USA. In our survey, the respondents also pointed out that troubles with speaking English come from the lack of information about everyday, social, economic, political life of the target country: "[...] it means I could not keep to the same level, because I did not speak English and that means some things were more difficult for me. It was, for instance, I knew nothing about American way... American political science. Nobody could teach us such things" (Iryney, 79 y.o.).

Despite learning English for a long time, respondents living in the USA claim they do not feel like they speak fluent English (as their mother tongue). A part of the respondents emphasises their accent or poor English is often forgiven since the USA is a state of immigrants, and people here usually are eager to help each other to communicate.

The interview has revealed that some of the Ukrainians who speak English very well have a specific accent when speaking Ukrainian. Also, they are getting in troubles when speaking Ukrainian because of permanent use of English. Herewith, according to our observations over the conducted interviews, representatives of the "new" wave use lots of Briticisms and Russisms when speaking Ukrainian. On the other hand, representatives of the post-WWII wave use Ukrainian archaisms (the language used in Ukraine in the middle of the $20^{\text {th }}$ century) and Polonisms ${ }^{35}$ more than Briticisms and barely use Russisms.

Studying language identity, we suggest considering three main groups of factors determining it, namely the language the respondents speak at home, at work and with friends.

The interviewed Ukrainians in the USA speak mainly Ukrainian or Russian at home. Speaking Russian is common with the fourth wave immigrants' families where a wife or a husband (or both) is Russian-speaking and was Russian-speaking before migration. Respondents' children, or the "second generation" are usually

of the mother tongue among the grandchildren of contemporary immigrants, "Demography" 2002, Vol. 39(3), pp. 467-484.

35 A word, idiom or phrase characteristic of British English, Russian or Polish respectively. 
bilingual (speak Ukrainian/Russian and English) or speak even three languages (Ukrainian, English and Russian). Such multilingualism often appears when switching from English to Ukrainian/Russian or vice versa at home is a usual case. Although, these are also cases when that "second generation" speak only Ukrainian or Russian at home.

A great majority of respondents speak English at work and this is quite expectable. Many respondents point out well-paid job possibility as a reason to learn English. Some respondents yet learn English directly at working place. It is typical for some representatives of the fourth wave to use not only English but also Ukrainian and/or Russian at work. It should be noted that such job's responsibilities (full-time or part-time) have to include:

- translation (from Ukrainian and/or Russian to English or vice versa),

- communication with Ukrainian/Russian speakers (employers, co-workers, clients),

- engagement in education requiring certain language speaking skills (kindergarten, school, college, university).

The main languages of respondents' communication with friends are Ukrainian, Russian and English. The interviewed Ukrainian immigrants in the USA use English communicating with friends who do not speak Ukrainian or Russian. The respondents speak Ukrainian (Russian) communicating with friends of Ukrainian origin and speak Russian with immigrants from other former Soviet republics and sometimes Russian-speaking Ukrainians or:

[...] if I know that this person is of Ukrainian origin and understands Ukrainian but speaks Russian, I would quite peacefully listen to her/his Russian and answer in Ukrainian. If a person is not related to and does not understand Ukrainian, I would speak Russian. If a person is American, I would obviously speak English (Olya, 45 y.o.).

Communication in Ukrainian with Ukrainians and in English with other interlocutors is common for representatives of the third wave. These respondents admit they do not like the fact Ukrainians (new generation of Ukrainians in the USA and the fourth wave immigrants) in Ukrainian surroundings speak English. This promotes circulation of English within the Ukrainian community and stimulates its assimilation. Alongside, respondents often note that their children do speak Ukrainian:

I thought that kids had gone to school, then college, so Ukrainian was forgotten. I was surprised how briskly did Ukrainian come back. I just watched her [daughter] haggling with grannies at the market on Podil ${ }^{36}$. She was buying some stuff there and she talked to them with that accent.

36 A place in central part of Kyiv, the capital of Ukraine. 
Pobrane z czasopisma Annales I - Philosophy and Sociology http://philosophia.annales.umcs.pl Data: 26/04/2023 12:16:53

Comparative Analysis of the Identity and Practices of Post-war Representatives...

It was amazed. I want to tell you that my son, he also reads now in Ukrainian, he recalls it because they were taught [Ukrainian] when they were kids. It was challenging time because they went to school after nursery, Ukrainian died away for them, because of English, English all the time, college - English, university - English. If they had lived with dad and mom they would have spoken Ukrainian to each other at least at home. Well, Ukrainian is coming back anyway. I am very happy with that (Yuriy, 85 y.o.).

From the above, we can assume that language practices and corresponding identities of Ukrainians in the USA are not homogeneous. They are composed of at least two constituent parts, namely Ukrainian/Russian and English ones. Also, very often they have all these three constituents, the priority of which being determined by the communication context (place of communication, interlocutors, circumstances).

The first three waves of Ukrainian immigration to the USA are characterised by Ukrainian-speaking migrants. Besides, due to historic events and political situation in Ukraine, a part of them were also speaking Polish, Russian or German. Nowadays Ukrainian is taught at a number of universities in the USA, there are also departments of Ukrainian literature at big public libraries. Nevertheless, the number of Ukrainians in the USA speaking Ukrainian was less than $17 \%$ in the 1980 s because of language assimilation ${ }^{37}$. Taking into consideration that newcomers make about $17 \%$ of Ukrainians in the USA, the number of Ukrainian-speaking population has significantly increased in the course of assimilation of the fourth wave. According to experts' data, Ukrainian-speaking Ukrainians in the USA would nowadays have been less than $7 \%$ in case the fourth wave had not migrated ${ }^{38}$. According to official statistics ${ }^{39}$, the number of Ukrainian-speaking Ukrainians in the USA is about 150,000. At the same time, the number of Ukrainians and people of declared Ukrainian ancestry is, as was mentioned above, about a million.

A specific language feature of the fourth immigration wave is a great number of Russian-speaking Ukrainians counting about a half of its representatives. There are, however, some distinctions between age groups. The trend is as follows: the younger the age group, the greater the number of Ukrainian-speaking Ukrainians (in comparison to Russian-speaking) in $\mathrm{it}^{40}$. Even though Ukrainian immigrant community is characterised by a share of Russian-speaking, it is still considered to be one of the least language-assimilated communities from Eastern and South-Eastern European countries in the USA due to the fourth

\footnotetext{
37 M.P. Fedunkiw, op. cit.

38 V. Lopukh, op. cit., p. 200.

39 People Reporting...

40 O. Wolowyna, op. cit.
} 
wave $^{41}$. We have observed that immigrants representing the third wave and the descendants of the first waves of Ukrainian immigration often evaluate the newcomers as "infusion of fresh blood" into Ukrainian diaspora in general and Ukrainian diaspora organisations in particular. Herewith, the representatives of the crystallised during the previous decades Ukrainian diaspora do not always accept speaking Russian by representatives of the "new" wave. In its turn, the fourth wave immigrants do not hurry to join the traditional Ukrainian organisation in the USA, choosing alternative forms of interaction.

\section{CONCLUSIONS}

Results of the conducted research drive us to the conclusion that Ukrainian immigrants in the USA of the third (post-WWII) and fourth (post-1990s) waves have some similarities as well as differentiating features in respect of ethnocultural identities and corresponding practices.

It is natural that the composition of the national identity of the third wave (post-WWII) immigrants is devoid of Soviet-minded constituent due to historical circumstances. Besides, both third and fourth wave comers consider US citizenship not as a marker of national identity, but as the consequence of involuntary refusal from their Ukrainian citizenship and mandatory belonging to the receiving state (for the third wave respondents) or as an instrument to overcome bureaucratic barriers (for the respondents of the fourth wave). The reason is that the USA is usually taken as "a state of immigrants" in general and impelled immigrants in particular (for the respondents of the third wave). The peculiar similarity between the "new" and "old" waves is their specific indissoluble connection with the state of Ukraine, at the same time denying any association with Ukrainian political elites and their activities in different historical periods.

Ethnic identity of the interviewed Ukrainians in the USA has self-naming (surface form) and is implemented in definite practices and common activity based on the sense of belonging to the Ukrainian ethnos. Moreover, the deep form of this identity is characteristic of Ukrainian immigrants: Ukrainian ethnic practices are reproduced in the exile through following traditions and infrastructure development: Sunday/Saturday schools, art groups, workshop, shops selling "Ukrainian" goods, Ukrainian organisations. Despite this, representatives of the fourth wave are inclined to participate in modern non-formal organisations, communities, networks rather than in traditional immigrants' organisations. This kind of common

${ }^{41}$ M. Robila, Eastern European immigrants in the United States: A socio-demographic profile, "The Social Science Journal” 2007, No. 44, pp. 113-125. 
Pobrane z czasopisma Annales I - Philosophy and Sociology http://philosophia.annales.umcs.pl Data: 26/04/2023 12:16:53

Comparative Analysis of the Identity and Practices of Post-war Representatives...

activities of Ukrainians aboard is more effective for social and political spheres, while it is almost ineffective in cultivating the reproduction of Ukrainian ethnic practices. At the same time, activities of "old" waves traditional organisations are directed at maintaining Ukrainian ethnic practices and they usually do not use all the modern methods of communication which deprives them of being able to react quickly to challenges of modern social and political life.

In our opinion, there are no significant differences in ethnic identity of the third and fourth immigrant waves, but some signs of divergence can be seen in their cultural identity. In particular, the Ukrainian constituent of cultural identity and corresponding practices of the post-WWII migration wave is built on Ukrainian national and Ukrainian ethnic belonging. But cultural identity constituent of the newcomers is rather complex and is built on Ukrainian ethnic and national belonging as well as on cultural practices related to the Soviet period of Ukrainian history and reproducing the elements of other cultures widespread in independent Ukraine.

We also conclude that language identity and corresponding practices of Ukrainians in the USA are heterogeneous and contain several constituent elements. Besides, we have detected definite opposition between the last two main waves of Ukrainian immigrants in the USA as far as languages issues are regarded. It mainly concerns Russian as the language of everyday use for the fourth wave representatives, caused by certain historical circumstances.

Having taken all the above together, there arises a question: In what way will Ukrainian ethnocultural practices be reproduced in future? Despite all the divergences, representatives of post-WWII wave still consider "new" immigrants as a chance to maintain the Ukrainian way of life, language, traditions, organisations in the USA when the third wave survivors pass away. Analysing the results obtained in current research, we assume that the "new" wave of Ukrainian diaspora in the USA will manage to perform this function, at least partly. We suppose that Ukrainians in exile will henceforth reproduce the cultural practices widespread in Ukraine at the moment of emigration, as well as Ukrainian national and language practices and the most peculiar Ukrainian ethnic practices alongside the American ones. This hypothesis may be developed in further ethnosociological, anthropological, cultural and migration studies.

\section{REFERENCES}

Alba R.J., Logan J., Stults B., Only English by the third generation? Loss and preservation of the mother tongue among the grandchildren of contemporary immigrants, "Demography" 2002, Vol. 39(3).

Azhnyuk B., Natsional'na identychnist' i mova v ukrayins'kiy diaspori, "Suchasnist" 1999, Vol. 3 (in Ukrainian). 
Detailed Languages Spoken at Home and Ability to Speak English for the Population 5 Years and Over: 2009-2013, www.census.gov/data/tables/2013/demo/2009-2013-lang-tables.html [access: 20.12.2017].

Fedunkiw M.P., Ukrainian Americans, www.everyculture.com/multi/Sr-Z/Ukrainian-Americans. html [access: 20.12.2017].

Fink S.D., From 'Chicken Kiev' to Ukrainian recognition: Domestic politics in U.S. foreign policy toward Ukraine, "Harvard Ukrainian Studies" 1997, Vol. 21(1/2).

Gans H.J., Toward a reconciliation of 'assimilation' and 'pluralism': The interplay of acculturation and ethnic relation, "International Migration Review" 1997, Vol. 31(4).

Halich W., Ukrainian farmers in the United States, "Agricultural History" 1936, Vol. 10(1).

Kofler A., Migration, Emotions, Identities. The Subjective Meaning of Difference, Wien 2002.

Lemekh H., Ukrainian Immigrants in New York: Collision of Two Worlds, El Paso 2010.

Lopukh V., The effects of the 'Fourth Wave' of immigrants from Ukraine on the Ukrainian diaspora in the United States, "Demography and Social Economy" 2014, Vol. 1(21).

Migration in Ukraine: A Country Profile, ed. S. Siar, Geneva 2008.

Morris D., 'Gone to work to America': Irish step-migration through south Wales in the 1860 s and 1870s, "Immigrants \& Minorities" 2016, Vol. 34(3).

Nagurney M.J., The teaching of Ukrainian in the United States, "American Slavic and East European Review" 1945, Vol. 4(3/4).

People Reporting Ancestry, http://factfinder.census.gov/faces/tableservices/jsf/pages/productview. xhtml?pid=ACS_15_1YR_B04006\&prodType=table [access: 20.12.2017].

Procko B.P., The Ukrainian Catholic Church, 1945-1975, [in:] A Symposium Held at La Salle College in Philadelphia, Pennsylvania, April 19, 1975, eds. M. Labunka, L. Rudnytzky, Philadelphia 1976.

Procko B.P., Ukrainian Catholics in America: A History, Washington 1982.

Procko B.P., Ukrainians in Pennsylvania: A Contribution to the Growth of the Common Wealth, Philadelphia 1976.

Robila M., Eastern European immigrants in the United States: A socio-demographic profile, "The Social Science Journal" 2007, No. 44.

Rovenchak O., Sociokulturni osobliwosti suczasnoï ukraïns'koï jemigraciï do Nimieczczini, “Odesa National University Herald. Sociology and Politics" 2016, Vol. 21(1) (in Ukrainian).

Rovenchak O., Volodko V., Miżnarodna migraciia: tieoriia ta praktika, Lviv 2015 (in Ukrainian). Sarancha H., Suczasna jemigraciia w SSZA: problemi adaptaciï ta zbierieżennia widnosin z Ukrä̈noju, „Naukovi zapysky Ternopil'skoho nacional'noho pedahohichnoho universytetu im. Volodymyra Hnatjuka. Serija Istorija" 2010, No. 2 (in Ukrainian).

Ukrainian Immigrant Dwellings and Churches in North Dakota from Early Settlement until the Present, National Register of Historic Places, The State of North Dakota, 1987.

Vasylkiv Ch., Ukraïns'ka szkoła w SSZA: istoriia, problemi, pierspiektiwi ta rozwitok, "Theory and Practice of Teaching Ukrainian as a Foreign Language" 2014, No. 9 (in Ukrainian).

Volodko V., Jemigraciia z Ukraïni ta Polszczi. Pierietworiennia migracijnich rieżymiwk, [in:] Social science: Past, Present and Future. Collection of Papers of International Conference (Kyiv, September, 5-6, 2014), Kyiv 2014 (in Ukrainian).

Wolowyna O., Recent migration from Ukraine to the United States: Demographic and socio-economic characteristics, "The Ukrainian Quarterly" 2005, Vol. 61(3).

World Migration: Global Migration Flows, www.iom.int/world-migration [access: 20.12.2017]. 
Pobrane z czasopisma Annales I - Philosophy and Sociology http://philosophia.annales.umcs.pl Data: 26/04/2023 12:16:53

Comparative Analysis of the Identity and Practices of Post-war Representatives... 53

\section{STRESZCZENIE}

W artykule omówiono szczególne cechy narodowe, etniczne i kulturowe ukraińskich imigrantów w Stanach Zjednoczonych. Podstawę stanowiły wywiady przeprowadzone wśród Ukraińców mieszkających w USA i reprezentujących dwie fale imigracji ukraińskiej w XX w.: falę powojenną i współczesną. Opracowanie wskazuje podobieństwa i różnice ich tożsamości oraz odpowiadające im praktyki. Stosując metodę dyskursu i analizy porównawczej, autorki pokazują, że podobieństwa przeważają na poziomie etnicznej i narodowej tożsamości oraz praktyk amerykańskich imigrantów z Ukrainy, podczas gdy znaczące kontrowersje dotyczą ich poziomu kulturowego i językowego.

Słowa kluczowe: imigranci ukraińscy w Stanach Zjednoczonych; tożsamość; praktyka; kulturowy; etniczny; język; narodowość

\section{SUMMARY}

The article discusses specific national, ethnic and cultural attributes of Ukrainian immigrants in the USA. This is an interview-based study of Ukrainians experiencing living in the USA and representing the two waves of Ukrainian immigration in the USA in the $20^{\text {th }}$ century: the post-WWII wave and the contemporary wave, which reveals similarities and differences of their identities and corresponding practices. Applying methods of discourse and comparative analysis, the study shows that similarities prevail on the levels of ethnic and national identities and practices of US Ukrainian immigrants, whereas significant controversy is found on their cultural and language levels.

Keywords: Ukrainian immigrants in the USA; identity; practice; cultural; ethnic; language; national 